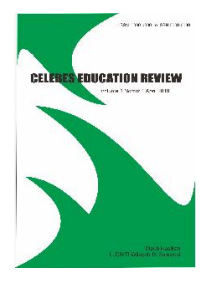

Celebes Education Review

http://journal.lldikti9.id/CER/index

Vol 1, No, 2, October 2019, pp 99-104

p-ISSN: 2656-7385 dan e-ISSN: 2684-7124

\title{
Komparasi Hasil Belajar Siswa Yang Diajar Dengan Pembelajaran Kooperatif Tipe Make A Match Dan Tipe Two Stay Two Stray
}

\author{
Anna Sulfianti ${ }^{1}$ \\ 1 Pendidikan Matematika, Sekolah Tinggi Ilmu Ekonomi Yapti Jeneponto \\ Email: anna.sulfianti91@gmail.com
}

\section{Artikel info}

Artikel history:

Received; 23-08-2019

Revised:21-09-2019

Accepted;08-10r-2019
Abstract. Problems that arise in the learning process are caused by lack of communication between the teacher and students. One of them is a negative attitude towards the field of mathematics study which considers the field of mathematics study is a difficult subject to understand so they are not motivated to study mathematics. Based on research conducted by several researchers previously suggested that learning mathematics through cooperative learning type TSTS and Make a Match can improve student learning outcomes. Both of these learning are applied with the reason to improve the learning that has been applied by the teacher in the teaching and learning process and to find out whether there are differences in mathematics learning outcomes achieved by students. This research is a quasiexperimental research involving two groups, namely one group as an experiment and one experimental group 2. The collection of data for student learning outcomes is done by giving a test of learning outcomes after being treated in each group, namely the experimental group I and the experimental group II. The data obtained is empirical data which will then be analyzed. Student learning outcomes taught by the Make A Match cooperative learning model are the same as the TSTS cooperative learning model because the scores of student learning outcomes taught using the cooperative learning model Make A Match type have no difference which is significant compared to the learning outcomes of students taught by the type two stay two stray cooperative learning model.

Abstrak. Masalah yang timbul dalam proses belajar mengajar disebabkan kurang terjalin komunikasi antara guru dan siswa. Salah satunya adalah sikap negatif terhadap bidang studi matematika yang menganggap bidang studi matematika adalah pelajaran yang sulit dipahami sehingga mereka tidak termotivasi untuk mempelajari matematika. Berdasarkan penelitian yang dilakukan oleh beberapa peneliti sebelumnya mengemukakan bahwa pembelajaran matematika melalui pembelajaran kooperatif tipe TSTS dan Make a Match dapat 
meningkatkan hasil belajar siswa. Kedua pembelajaran ini diterapkan dengan alasan untuk memperbaiki pembelajaran yang selama ini diterapkan oleh guru dalam proses belajar mengajar dan untuk mengetahui ada tidaknya perbedaan hasil belajar matematika yang dicapai oleh siswa.Penelitian ini adalah penelitian eksperimen semu yang melibatkan dua kelompok, yaitu satu kelompok sebagai eksperimen 1 dan satu kelompok eksperimen 2. Pengumpulan data untuk hasil belajar siswa dilakukan dengan pemberian tes hasil belajar setelah diberi perlakuan pada masing-masing kelompok, yaitu kelompok eksperimen I dan kelompok eksperimen II. Data yang diperoleh merupakan data empirik yang kemudian akan dianalisis.Hasil belajar siswa yang diajar dengan model pembelajaran kooperatif tipe Make A Match sama dengan model pembelajaran kooperatif tipe TSTS karena skor hasil belajar siswa yang diajar dengan menggunakan model pembelajaran kooperatif tipe Make A Match tidak memiliki perbedaan yang signifikan dibanding hasil belajar siswa yang diajar dengan model pembelajaran kooperatif tipe two stay two stray.

\section{Keywords:}

Hasil Belajar

siswa; model

pembelajaran tipe

TSTS; model

pembelajaran tipe

Make A Match.
Coresponden author:

Email: xxxx@gmail.com

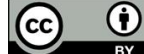

artikel dengan akses terbuka dibawah lisensi CC BY -4.0

\section{Pendahuluan}

Masalah yang timbul dalam proses belajar mengajar disebabkan kurang terjalin komunikasi antara guru dan siswa. Salah satunya adalah sikap negatif terhadap bidang studi matematika yang menganggap bidang studi matematika adalah pelajaran yang sulit dipahami sehingga mereka tidak termotivasi untuk mempelajari matematika.

Banyak permasalahan terlihat bahwa cara guru dalam menyajikan materi/pelajaran di sekolah masih bersifat menoton, guru yang terlihat aktif dalam setiap proses belajar mengajar. Siswa hanya fokus pada guru sebagai sumber pelajaran. Proses pembelajaran di kelas diarahkan kepada kemampuan anak untuk menghafal informasi tanpa dituntut untuk memahami informasi tersebut. Proses pembelajaran di kelas diarahkan kepada kemampuan anak untuk menghafal informasi tanpa dituntut untuk memahami informasi tersebut. Selain itu, ada rasa takut dan malu bertanya, kurang melibatkan diri secara aktif dalam belajar. Padahal mereka mempunyai kemauan yang tinggi untuk mengetahui tentang apa yang mereka pelajari. Jika ditinjau dari kemampuan, dan keheterogenan siswanya sebenarnya pola pembelajaran kooperatif dapat diterapkan di sekolah ini. Siswa yang memiliki tingkat kemampuan tinggi, sedang, dan rendah serta berasal dari berbagai latar belakang sosial yang berbeda. Semua itu memenuhi kriteria pembentukan satu kelompok dalam pembelajaran kooperatif yang jika dimanfaatkan dan dikelola dengan baik maka diharapkan dapat memperbaiki dan meningkatkan keaktifan serta kemampuan siswa dalam proses belajar mengajar.

Pembelajaran kooperatif merupakan model pembelajaran yang menjadi perhatian serta dianjurkan oleh para ahli pendidikan seperti David W. Johnson dan Roger T. Johnson. Berdasarkan penelitian yang dilakukan sebelumnya oleh Sanimbar (Erliyanti, 2011: 2) mengemukakan bahwa pembelajaran matematika melalui pembelajaran kooperatif tipe Two Stay Two Stray dapat meningkatkan hasil belajar siswa. Begitupun penelitian yang dilakukan oleh Miftahuddin (Erliyanti, 2011: 3) juga mengatakan bahwa penerapan pembelajaran 
kooperatif tipe Make A Match dalam pembelajaran matematika dapat meningkatkan kualitas proses belajar siswa. Jadi, kedua pembelajaran ini sama-sama dapat memperbaiki dan meningkatkan mutu pembelajaran dimana pembelajaran ini memberi penekanan pada struktur tertentu yang dirancang untuk mempengaruhi pola interaksi siswa. Dari hasil pengamatan tersebut maka dicobalah untuk menerapkan pembelajaran kooperatif tipe Two Stay Two Stray dan Make A Match.

Two Stay Two Stray adalah tipe dua tinggal dua tamu yang memberikan kesempatan kepada kelompok untuk membagikan hasil dan informasi ke kelompok yang lain. Penggunaan model pembelajaran kooperatif TSTS akan mengarahkan siswa untuk aktif, baik dalam berdiskusi, tanya jawab, mencari jawaban, menjelaskan, dan juga menyimak materi yang dijelaskan oleh teman. Selain itu, alasan menggunakan model pembelajaran Two Stay Two Stray ini karena terdapat pembagian kerja kelompok yang jelas tiap anggota kelompok, siswa dapat bekerjasama dengan temannya, selanjutnya Make A Match merupakan pembelajaran yang menggunakan kartu-kartu. Kartu-kartu tersebut terdiri dari kartu berisi pertanyaan-pertanyaan dan kartu-kartu lainnya berisi jawaban dari pertanyaan-pertanyaan tersebut.

Kedua pembelajaran ini diterapkan dengan alasan untuk memperbaiki pembelajaran yang selama ini diterapkan oleh guru dalam proses belajar mengajar dan untuk mengetahui ada tidaknya perbedaan hasil belajar matematika yang dicapai oleh siswa.Berdasarkan pemikiran tersebut, maka penulis bermaksud melaksanakan penelitian dengan judul "Komparasi Hasil Belajar Siswa yang Diajar Dengan Pembelajaran Kooperatif Tipe Make A Match dan Tipe Two Stay Two Stray di kelas VII SMP Negeri 3 Tompobulu Kabupaten Bantaeng".

\section{Metode Penelitian}

Penelitian ini adalah penelitian eksperimen semu yang melibatkan dua kelompok, yaitu satu kelompok sebagai eksperimen 1 dan satu kelompok eksperimen 2. Kelompok eksperimen 1 diajar dengan pembelajaran kooperatif tipe Make A Match sedangkan kelompok eksperimen 2 diajar dengan pembelajaran kooperatif tipe Two Stay Two Stray. Adapun populasi dari penelitian ini adalah seluruh siswa kelas VII SMP Negeri 3 Tompobulu Kabupaten Bantaeng dengan jumlah siswa sebanyak 36 pada tahun ajaran 2018/ 2019 yang terdiri dari lima kelas. Sampel dalam penelitian ini terdiri dari 2 kelas, Satu kelas menjadi kelompok eksperimen 1 yaitu kelas VIIA diajar dengan menggunakan pembelajaran kooperatif tipe Make A Match dan satu kelas menjadi kelompok eksperimen 2 yaitu yaitu kelas VIIB diajar dengan menggunakan pembelajaran kooperatif tipe Two Stay Two Stray. Pengumpulan data untuk hasil belajar siswa dilakukan dengan pemberian tes hasil belajar setelah diberi perlakuan selama beberapa kali pertemuan pada masing-masing kelompok, yaitu kelompok eksperimen I dan kelompok eksperimen II. Data yang diperoleh merupakan data empirik yang kemudian akan dianalisis. Teknik analisis data yang digunakan dalam penelitian ini adalah:

\section{Analisis Statistika Deskriptif}

Analisis yang menekankan pada pembahasan data-data dan subjek penelitian dengan menyajikan data-data secara sistematik dan tidak menyimpulkan hasil penelitian. Di samping itu hasil belajar siswa juga diarahkan pada pencapaian hasil belajar secara individual dan klasikal. Kriteria seorang siswa dikatakan tuntas belajar apabila memenuhi KKM yang ditentukan oleh sekolah, sedangkan ketuntasan klasikal tercapai apabila minimal 70\% siswa di kelas tersebut telah mencapi skor ketuntasan minimal.

2. Analisis Statistika Inferensial

Statistika inferensial adalah teknik statistik yang digunakan untuk menganalisis data sampel dan hasilnya diberlakukan untuk populasi. Teknik statistik ini dimaksudkan untuk menguji hipotesis penelitian. Sebelum menguji hipotesis penelitian, dilakukan uji normalitas dan 
uji homogenitas. Untuk menguji hipotesis nol, bahwa rata-rata dua buah kelompok tidak berbeda maka digunakan t-Test. Namun pada dasarnya keduanya akan menghasilkan kesimpulan yang sama, yaitu menerima atau menolak hipotesis nol.

Dari hasil penelitian inferensial menunjukkan bahwa data hasil belajar siswa berdistribusi normal dan memiliki varian yang sama (homogen). Begitu pula dengan pengujian hipotesis yang menunjukkan bahwa $\mathrm{H}_{0}$ diterima.

\section{Hasil Penelitian}

Hasil analisis statistika deskriptif menunjukkan deskripsi tentang karakteristik distribusi skor hasil belajar dari masing-masing kelompok penelitian sekaligus jawaban atas masalah yang dirumuskan dalam penelitian penelitian menunjukkan bahwa rata-rata skor hasil belajar siswa pada pokok bahasan bentuk aljabar yang diajar dengan model pembelajaran kooperatif tipe Make A Match adalah 81,39 menunjukkan bahwa tingkat hasil belajar siswa pada kelas eksperimen 1 setelah diberi perlakuan berada pada kategori "tinggi". Modus kelas eksperimen 1 sebesar 89 , yang menerangkan bahwa skor 89 adalah skor yang paling banyak diperoleh dari 18 siswa Median, dimana nilai tertingginya 96 dan terendah 65 ini menunjukkan bahwa skor yang diperoleh berada pada kategori sedang, tinggi, dan sangat tinggi. Ukuran Dispersi atau Penyimpangan yang meliputi rentang sebesar 31 menunjukkan bahwa jarak antara kedua nilai (nilai tertinggi dan terendah). Hasil penelitian menunjukkan bahwa dari 18 orang siswa kelas $\mathrm{VII}_{\mathrm{A}}$ SMP Negeri 3 Tompobulu Kabupaten Bantaeng yang dijadikan sampel penelitian untuk kelompok eksperimen 1 yang diajar melalui model kooperatif tipe Make A Match pada pokok bahasan bentuk aljabar, pada umumnya memiliki tingkat hasil belajar matematika dalam kategori tinggi dan tidak satupun siswa yang memperoleh nilai sangat rendah maupun rendah.

Secara deskriptif, perlakuan melalui model kooperatif tipe Make A Match, ternyata mampu meningkatkan hasil belajar siswa. Rata-rata skor hasil belajar siswa pada pokok bahasan bentuk aljabar yang diajar dengan model pembelajaran kooperatif tipe Two Stay Two Stray adalah 77,11 menunjukkan bahwa tingkat hasil belajar siswa pada kelas eksperimen 1 setelah diberi perlakuan berada pada kategori "sedang".

a. Modus kelas eksperimen 2 sebesar 63, yang menerangkan bahwa skor 63 adalah skor yang paling banyak diperoleh dari 18 siswa.

b. Median, dimana nilai tertingginya 94 dan terendah 59 ini menunjukkan bahwa skor yang diperoleh berada pada kategori rendah, sedang, tinggi, dan sangat tinggi.

c. Berdasarkan hasil penelitian menunjukkan bahwa dari 18 orang siswa kelas $\mathrm{VII}_{B}$ SMP Negeri 3 Tompobulu Kabupaten Bantaeng yang dijadikan sampel penelitian untuk kelompok eksperimen 2 yang diajar melalui model kooperatif tipe Two Stay Two Stray pada pokok bahasan bentuk aljabar, pada umumnya memiliki tingkat hasil belajar matematika dalam kategori tinggi dan tidak satupun siswa yang memperoleh nilai sangat rendah. Secara deskriptif, perlakuan melalui model kooperatif tipe Two Stay Two Stray, ternyata mampu meningkatkan hasil belajar siswa. skor rata-rata siswa siswa yang diajar dengan menggunakan model pembelajaran kooperatif tipe Make A Match lebih tinggi yaitu 81,39 dengan rentang skor 31 dibanding dengan model pembelajaran kooperatif tipe Two Stay Two Stray yaitu 77,11 dengan rentang skor 35 .

\section{Pembahasan}

Hasil penelitian deskriptif menunjukkan bahwa hasil belajar matematika siswa kelas $\mathrm{VII}_{\mathrm{A}}$ SMP Negeri 3 Tompobulu Kabupaten Bantaeng pada pokok bahasan bentuk aljabar, yang diajar dengan menggunakan model pembelajaran kooperatif tipe Make A Match dikategorikan tinggi. 
Hal ini terlihat dari Distribusi dan persentase skor hasil belajar yaitu kategori sedang 44,4\%, kategori tinggi 50\% dan kategori sangat tinggi 5,6\%, dengan skor rata-rata sebesar 81,39 dari skor ideal yang mungkin dicapai yaitu 100 berada pada interval 65 - 96 dengan standar deviasi 8.879 .

Sementara itu hasil belajar matematika siswa kelas $\mathrm{VII}_{\mathrm{B}}$ SMP Negeri 3 Tompobulu Kabupaten Bantaeng pada pokok bahasan bentuk aljabar yang diajar dengan menggunakan model pembelajaran kooperatif tipe Two Stay Two Stray dikategorikan sedang. Hal ini terlihat dari Distribusi dan persentase skor hasil belajar yaitu kategori rendah 27,8\%, kategori sedang 22,2\%, kategori tinggi 44,4\% dan kategori sangat tinggi 5,6\%, dengan skor rata-rata sebesar 77,11 dari skor ideal yang mungkin dicapai yaitu 100 berada pada interval 59 - 94 dengan standar deviasi 11.135 .

Berdasarkan Kriteria Ketuntasan Minimal yang digunakan di SMP Negeri 3 Tompobulu Kabupaten Bantaeng, siswa dikatakan tuntas belajar jika hasil belajarnya telah mencapai $\geq 70$ dan ketuntasan klasikal jika 70\% siswa telah mencapai skor $\geq 70$. Hal ini dicapai oleh kelas eksperimen 1 dan eksperimen 2, dengan siswa yang telah mencapai ketuntasan belajar di kelas eksperimen 1 sebanyak 16 orang dari jumlah keseluruhan 18 orang dengan persentase 88,89\%, sedangkan pada kelas eksperimen 2 siswa yang telah mencapai ketuntasan belajar sebanyak 13 orang dari jumlah keseluruhan 18 dengan persentase $72,2 \%$.

Hasil analisis inferensial menunjukkan bahwa terdapat perbedaan hasil belajar siswa pada pokok bahasan bentuk alajabar yang diajar dengan menggunakan model pembelajaran kooperatif tipe Make A Match dengan siswa yang diajar dengan model pembelajaran kooperatif tipe Two Stay Two Stray. tidak ada perbedaan secara signifikan. Hal ini ditunjukkan oleh nilai

$t_{\text {hitung }}<t_{\text {tabel }}$ yaitu $1,274<2,032$. Sehingga dapat disimpulkan bahwa hasil belajar matematika siswa yang diajar dengan menggunakan pembelajaran kooperatif tipe Make A Match sama dengan yang diajar dengan tipe Two Stay Two Stray pada kelas VII SMP Negeri 3 Tompobulu Kabupaten Bantaeng.

Berdasarkan hasil analisis inferensial terlihat bahwa hasil belajar matematika siswa yang diajar dengan menggunakan kooperatif tipe Make A Match dan Two Stay Two Stray tidak memiliki perbedaan yang signifikan. Bila ditinjau dari keaktifan belajar siswa dalam proses pembelajaran. Penggunaan model pembelajaran kooperatif TSTS mengarahkan siswa untuk aktif, baik dalam berdiskusi, tanya jawab, mencari jawaban, menjelaskan, dan juga menyimak materi yang dijelaskan oleh teman. Selain itu, pembagian kerja kelompok pada model pembelajaran Two Stay Two Stray ini jelas tiap anggota kelompok sehingga siswa dapat bekerjasama dengan temannya. Sedangkan pada penerapan pembelajaran kooperatif tipe Make A Match siswa juga siswa terlibat aktif karena siswa diberi kesempatan untuk berfikir secara individual untuk membangun asumsi awal atas pertanyaan dan jawaban dari masing-masing kartu yang dipegang. Siswa akan berusaha menemukan jawaban atau pertanyaan yang benar dengan menyatukan asumsi yang telah terbangun sebelumnya.

\section{Simpulan dan Saran}

Berdasarkan hasil analisis data dan pembahasan di atas maka dapat disimpulkan bahwa:

a) Hasil belajar siswa pada pokok bahasan bentuk alajabar di kelas $\operatorname{VII}_{A}$ SMP Negeri 3 Tompobulu Kabupaten Bantaeng yang diajar dengan model pembelajaran kooperatif tipe Make A Match memiliki skor rata-rata 81,39.

b) Hasil belajar siswa pada pokok bahasan bentuk alajabar di kelas $\operatorname{VII}_{B}$ SMP Negeri 3 Tompobulu Kabupaten Bantaeng yang diajar dengan model pembelajaran kooperatif tipe Two Stay Two Stray memiliki skor rata-rata 77,11. 
c) Hasil belajar siswa pada pokok bahasan bentuk alajabar di kelas VII SMP Negeri 3 Tompobulu Kabupaten Bantaeng yang diajar dengan model pembelajaran kooperatif tipe Make A Match sama dengan model pembelajaran kooperatif tipe Two Stay Two Stray karena skor hasil belajar siswa yang diajar dengan menggunakan model pembelajaran kooperatif tipe Make A Match tidak memiliki perbedaan yang signifikan dibanding hasil belajar siswa yang diajar dengan model pembelajaran kooperatif tipe two stay two stray.

\section{Saran}

Setelah melihat hasil penelitian yang telah dilakukan, maka penulis menyarankan bahwa:

a) Diharapkan kepada pendidik untuk menggunakan dan memilih pendekatan yang relevan dengan pembahasan materi pelajaran, untuk mempermudah dalam pencapaian kompetensi dasar.

b) Diharapkan kepada para peneliti dalam bidang pendidikan matematika supaya dapat meneliti lebih jauh tentang pendekatan, metode yang efektif dan efisien untuk mengatasi kesulitan siswa dalam belajar matematika.

\section{Refference}

Emzir. 2010. Metodologi Penelitian Pendidikan Kuantitatif \& Kualitatif. Jakarta: Rajawali Pers.

Erliyanti. 2011. Komparasi Hasil Belajar Matematika antara siswa yang diajar dengan Pembelajaran Kooperatif Tipe Two Stay Two Stray dan Make A Match Pada Kelas X Sma Negeri 1 Taka Bonerate Kabupaten Kepulauan Selayar. Skripsi tidak diterbitkan. Makassar: Unismuh Makassar.

Huda, Miftahul. 2011. Cooperatif Learning. Yogyakarta: Pustaka Pelajar.

Ibrahim, dkk. 2010. Pembelajaran Kooperatif. Surabaya: Surabaya University Press.

Nurmalia. 2011. Efektivitas Pendekatan Realistic Mathematic Education (RME) dalam Pembelajaran Matematika Pada Siswa Kelas VII SMP Nasional Makassar. Skripsi tidak diterbitkan. Makassar: Unismuh Makassar.

Suprijono, Agus. 2009. Cooperative Learning. Surabaya: Pustaka Pelajar.

Trianto. 2010. Mendesain Model Pembelajaran Inovatif-Progresif. Jakarta: Kencana. 